Article

\title{
Building Space Heating with a Solar-Assisted Heat Pump Using Roof-Integrated Solar Collectors
}

\section{Zhiyong Yang ${ }^{1, *}$, Yiping Wang ${ }^{1}$ and Li Zhu ${ }^{2}$}

1 School of Chemical Engineering and Technology, Tianjin University, 300072, Tianjin, China; E-Mail: xinxing@tju.edu.cn

2 School of Architecture, Tianjin University, 300072, Tianjin, China; E-Mail: zly_tj@163.com

* Author to whom correspondence should be addressed; E-Mail: yzy_tj@163.com; Tel.: +86-15801171269 or +86-13820104639; Fax: +86-22-27404771.

Received: 25 January 2011; in revised form: 2 March 2011 / Accepted: 7 March 2011 /

Published: 14 March 2011

\begin{abstract}
A solar assisted heat pump (SAHP) system was designed by using a roof-integrated solar collector as the evaporator, and then it was demonstrated to provide space heating for a villa in Tianjin, China. A building energy simulation tool was used to predict the space heating load and a three dimensional theoretical model was established to analyze the heat collection performance of the solar roof collector. A floor radiant heating unit was used to decrease the energy demand. The measurement results during the winter test period show that the system can provide a comfortable living space in winter, when the room temperature averaged $18.9^{\circ} \mathrm{C}$. The average $\mathrm{COP}$ of the heat pump system is 2.97 and with a maximum around 4.16 .
\end{abstract}

Keywords: building integration; solar roof tiles; heat pump; building space heating; simulation

\section{Nomenclature:}

$C_{p}=$ specific heat of fluid at constant pressure $\left(\mathrm{J} \mathrm{kg}^{-1} \mathrm{~K}^{-1}\right)$;

$h_{a}=$ ambient heat loss coefficient $\left(\mathrm{W} \mathrm{m}^{-2} \mathrm{~K}^{-1}\right)$;

$h_{c}=$ convection heat loss coefficient $\left(\mathrm{W} \mathrm{m}^{-2} \mathrm{~K}^{-1}\right)$;

$h_{f}=$ fluid heat transfer coefficient $\left(\mathrm{W} \mathrm{m}^{-2} \mathrm{~K}^{-1}\right)$;

$h_{r}=$ radiation heat loss coefficient $\left(\mathrm{W} \mathrm{m}^{-2} \mathrm{~K}^{-1}\right)$;

$I=$ solar insolation $\left(\mathrm{W} \mathrm{m}^{-2}\right)$;

$K=$ thermal conductivity $\left(\mathrm{W} \mathrm{m}^{-1} \mathrm{~K}^{-1}\right)$; 
$k_{t}=$ thermal conductivity of tile $\left(\mathrm{W} \mathrm{m}^{-1} \mathrm{~K}^{-1}\right)$;

$\operatorname{Pr}=$ Prandtl number;

$q=$ heat flux $\left(\mathrm{W} \mathrm{m}^{-2}\right)$;

$\mathrm{Re}=$ Renolds number;

$T=$ temperature $(\mathrm{K})$;

$T_{f}=$ fluid temperature $(\mathrm{K})$;

$T_{a}=$ ambient temperature $(\mathrm{K})$;

$T_{d p}=$ dew point temperature $(\mathrm{K})$;

$T_{\text {sky }}=$ temperature of sky $(\mathrm{K})$;

$T=$ time (s);

$V=$ velocity $\left(\mathrm{m} \mathrm{s}^{-1}\right)$;

$\rho=$ density $\left(\mathrm{kg} \mathrm{m}^{-3}\right)$;

$\varepsilon=$ average emittance;

$\varepsilon_{s k y}=$ emittance of the sky;

$\varepsilon_{t}=$ emittance of the tile;

$\lambda=$ coefficient of thermal conductivity $\left(\mathrm{W} \mathrm{m}^{-1} \mathrm{~K}^{-1}\right)$

\section{Introduction}

Building energy consumption accounts for approximately $25-30 \%$ of the total energy usage in China [1], while in some industrialized countries the number can reach $40 \%$ [2]. Of this energy, the percentage used for supplying domestic hot water and running HVAC systems uses the most part. Interest has been growing in the adoption of new methodologies to utilize solar energy effectively. Solar collectors for domestic hot water provision have been widely used, especially in China. Sometimes, a larger area solar collector can supply space heating, but at the same time it also brings up the cost. Furthermore, another issue solar collectors are facing, is how to integrate perfectly with the building envelope. The double-facade is the key reason that causes the problems of high cost and additional building construction load. Finding good ways to fulfill the building integration for city solar systems is quite essential, and recently some investigations have been proceeding towards this. By embedding the tubes directly underneath the roof concrete layer, the roof construction can absorb solar heat by using the concrete layer as the absorber. Thus, building integration of solar collectors can be accomplished by this functionalization usage of conventional construction materials. Several researchers have studied this type of collector and obtained some experimental and theoretical results (Bopshetty [3], Chaurasia [4], Bilgen and Richard [5]). Similar ways have been used by others. Medved [6] designed a large-panel unglazed roof-integrated liquid solar collector based on standard metal roofing. In 2004, Abbott presented a legend precast solar collector used for space heating and domestic hot water [7].

The most efficient way to reduce the collector heat loss is to lower the demand temperature to decrease the temperature difference between the solar collector panel and the ambient temperature. Using the collector as the heat pump heat source makes achieving a high solar heat collection efficiency while at the same time meeting the heat usage requirements feasible. For heat pumps, a 
basic factor of great importance for their successful application is the availability of a cheap, dependable heat source for the evaporator-preferably one at a relatively high temperature [8]. The coefficient of performance (COP) of a heat pump depends to the great extent on the temperature of the evaporator. Combining the heat pump and solar energy is a mutual beneficial way to increase the heat pump COP and the solar collector efficiency. The solar collector loop is used to boost the heat source temperature of the heat pump, thereby increasing the heat pump's annual and seasonal performance. Similarly, the heat pump can reduce the collector operating temperature, which allows for sustainable heat gains even under marginal weather conditions and the use of inexpensive, unglazed solar collectors. This combined system could operate more efficiently under a wide range of weather conditions and for more hours each day. Abundant work, both theoretical and experimental, has been done on solar assisted-heat pump systems [9-25]. The results presented show that the thermal efficiency of the collector which acts as the heat source of a heat pump system is high because of the lower temperature difference between the collector and the environment, while the heat pumps' annual and seasonal performance were increased by increasing the heat source temperature of the heat pumps.

A floor radiation heating system is an efficient way to achieve indoor thermal comfort with low-energy demands. Instead of heating and circulating air throughout the house, radiant heat warms objects - carpet, furniture and even people. The most favorable aspect of radiant floor heating systems is that by virtue of their design they possess significantly better potential for energy storage than hydraulic heating systems with baseboard or convector units [26,27].

In the present paper, a solar assisted heat pump (SAHP) system combining all the above new methodologies is put forward, and the actual performance was tested after it was demonstrated in a villa in Tianjin China.

\section{Design Process of the Proposed System}

The proposed system mainly consists of the solar roofing collector, which features high solar utilization efficiency and complete roof integration, the radiant heating floor end system, which guarantees the lower energy demand and more comfortable indoor environment, and a compressor and related devices, which couple the source and end part. System design was first done by considering every aspect, including but not limited to the building construction, local climate conditions, local energy saving regulations and component coupling. Optimization of the system is aimed at achieving minimal energy usage, the easiest operation and the least maintenance work.

\subsection{Building Description}

The test building is a three-story villa located in Tianjin city, with an overall floor area of $820 \mathrm{~m}^{2}$. Tianjin (latitude of $39^{\circ} 08^{\prime}$ and the longitude of $117^{\circ} 07^{\prime}$ ) lies in the cold climate zone in China. The design temperatures in winter and summer are $-9.4{ }^{\circ} \mathrm{C}$ and $33.9{ }^{\circ} \mathrm{C}$, respectively, and the corresponding desired indoor temperatures are $18{ }^{\circ} \mathrm{C}$ and $26{ }^{\circ} \mathrm{C}$. Conventionally, the space heating period last from November 15 to the following March 15, and the space cooling days are from June 1 to September 15 . 
Figure 1. Pictures showing the appearance the demonstration building. (a) South view; (b) North view.

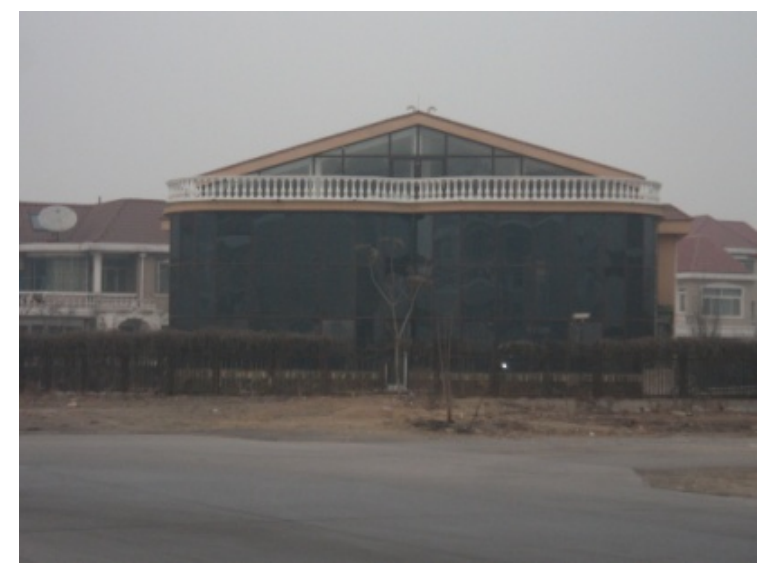

(a)

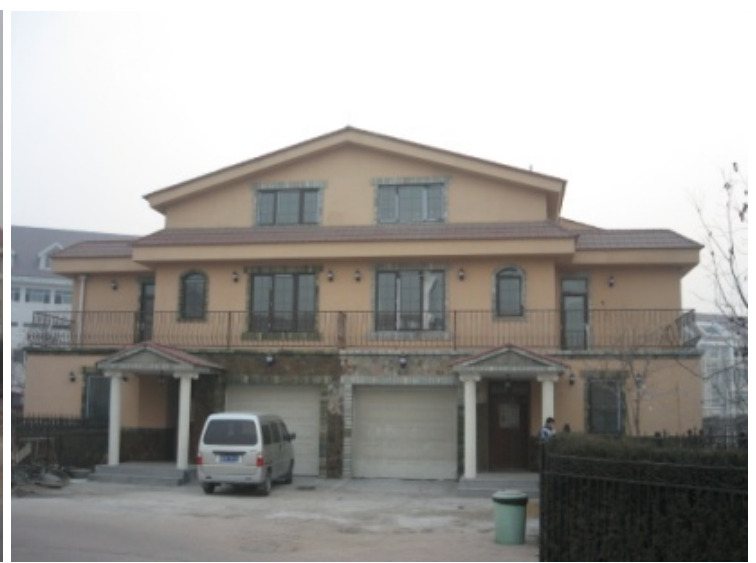

(b)

The villa was reconstructed for style retrofitting as well as to lower its energy usage. The building roof and wall construction were applied concrete and fired bricks, respectively. High thermal-insulation performance construction materials were utilized during the reconstruction, like the hollow double-glazing windows, expanded polystyrene (EPS) insulation boards (thickness: $80 \mathrm{~mm}$, $\lambda: 0.4 \mathrm{Wm}^{-2} \cdot \mathrm{k}^{-1}$ ) on the external walls, heat recovery units, and energy efficient appliances. The retrofitted building is shown in Figure 1.

\subsection{Space Heating Load Calculation}

The heating load provides the basic information for the energy system design. In the present paper, the eQUEST software tool was used to calculate the hourly building energy consumption. The eQUEST program is the latest official version of DOE-2 derived user-interface, which also extends and expands DOE-2's capabilities in several important ways: eQUEST calculates hour-by-hour building energy consumption over an entire year ( 8760 hours) using hourly weather data for the location under consideration [28-30].

Figure 2.The eQUEST building model.

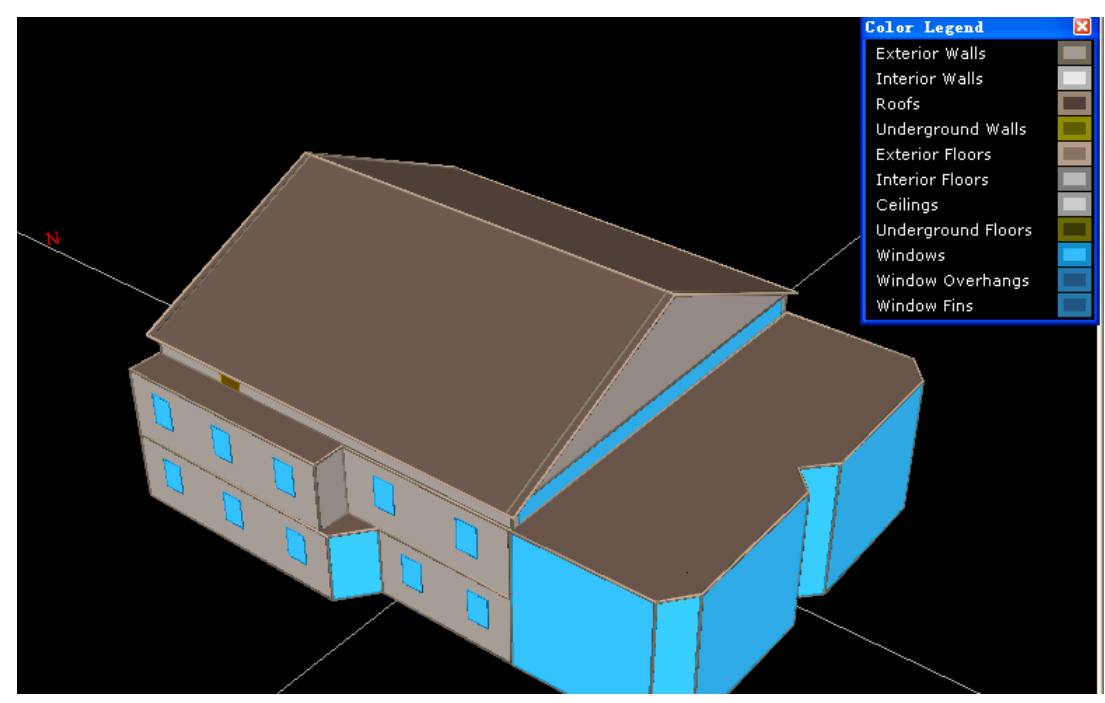


The geometric model of the building created by eQUEST is shown in Figure 2. Figure 3 gives the calculated hourly heating load obtained by inputting the building construction information, climate conditions, indoor thermostat temperature, system operation mode and related information,. Because the designed building roof was well insulated with the $80 \mathrm{~mm}$ EPS board, the influence of the roof-integrated solar collector wasn't taken into consideration. As seen from Figure 3, the peak heating load of the demonstrated villa in the whole winter is less than $34 \mathrm{~kW}$ and fluctuates with the weather conditions.

Figure 3. The heating load of the building during winter time.

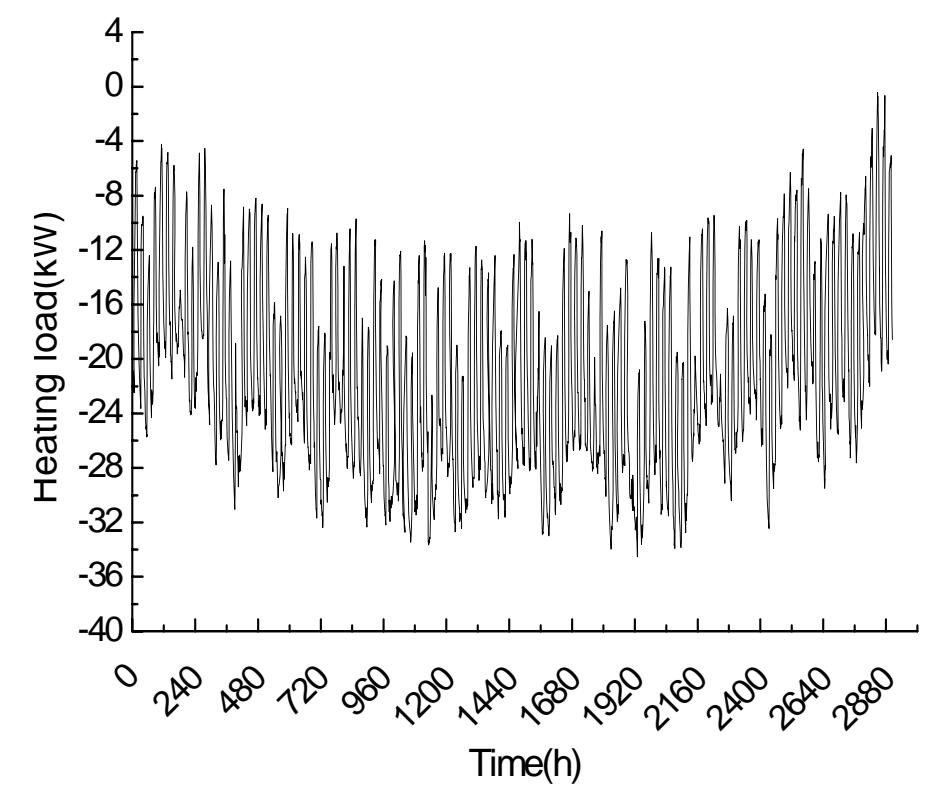

\subsection{Solar Roofing}

\subsubsection{Integration Structure}

The east-west aligned roof is sloped at an angle of $25^{\circ}$ and finished with ceramic tiles. Heat collecting devices were installed underneath the roof tiles, so from outside the solar collector is invisible and totally integrated into the building envelope as part of the roofing structure. Figure 4 shows the detailed roofing structure. After the EPS board was added to the roof structure, an aluminum mesh layer was laid, then the copper tube was arranged and covered with profiled aluminum strips, afterwards, a concrete layer was paved and finally finished with the ceramic tiles. The space between the pipes is $150 \mathrm{~mm}$. Table 1 lists the size and physical properties of the construction materials used. 
Figure 4. The arrangement of the solar collector.

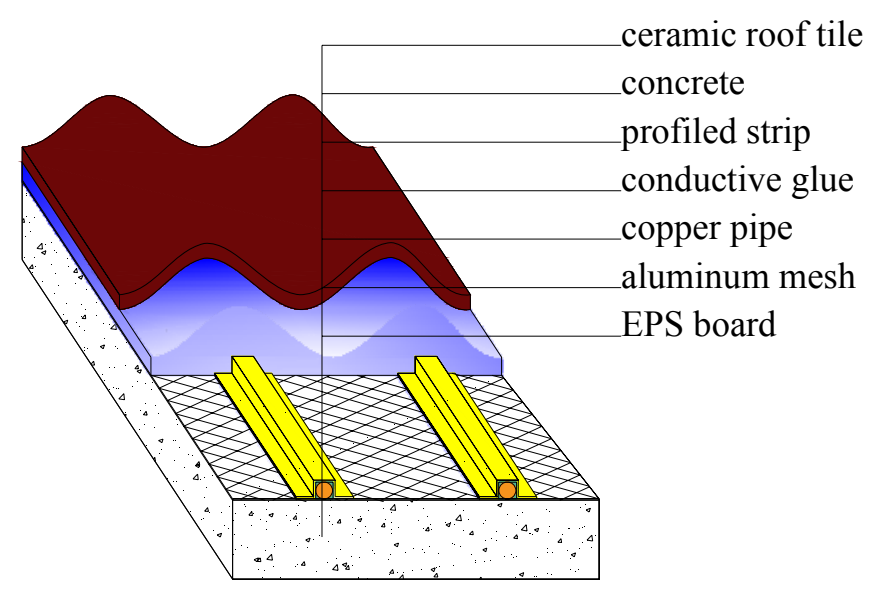

Table 1. The size and physical properties of the construction materials.

\begin{tabular}{lllll}
\hline Item & Feature Size $(\mathbf{m m})$ & $\boldsymbol{\lambda}(\mathbf{W} / \mathbf{m ~ K})$ & $\boldsymbol{\rho}\left(\mathbf{k g} / \mathbf{m}^{\mathbf{3}}\right)$ & $\mathbf{C}_{\mathbf{p}}(\mathbf{J} / \mathbf{k g ~ K})$ \\
\hline Copper tube & $8 \times 0.5$ & 398 & 8954 & 406 \\
Aluminum mesh plate & $3600 \times 1800$ & 227.8 & 2770 & 921 \\
Profiled strip & & 227.8 & 2770 & 921 \\
Ceramic tile & \multirow{2}{*}{$360 \times 270 \times 10$} & 0.72 & 2300 & 879 \\
Conductive glue & & 7 & 1755 & 545 \\
EPS & \multirow{2}{*}{$2000 \times 1000 \times 80$} & 0.035 & 30 & \\
Concrete paving & & 0.93 & 2400 & 920 \\
\hline
\end{tabular}

The structure of the aluminum mesh plate is shown in Figure 5a, where length $\mathrm{L}$ and width $\mathrm{B}$ of the mesh plate are $3.6 \mathrm{~m}$ and $1.8 \mathrm{~m}$, respectively, thickness $\mathrm{D}$ of the mesh plate is $2 \mathrm{~mm}$; the width of the mesh stalk is $4.95 \mathrm{~mm}$, the long pitch TL and short pitch of the mesh are $120 \mathrm{~mm}$ and $44 \mathrm{~mm}$, respectively. The structure of the profiled strip is shown in Figure $5 \mathrm{~b}$, the total width $\mathrm{W} 1$ is $28 \mathrm{~mm}$, the top width $\mathrm{W} 2$ is $10 \mathrm{~mm}$, the height is $10 \mathrm{~mm}$, and the depth $\mathrm{d}$ is $1 \mathrm{~mm}$.

Figure 5. The structure of the aluminum mesh plate and profiled strip. (a) Aluminum mesh plate; (b) Profiled strip.

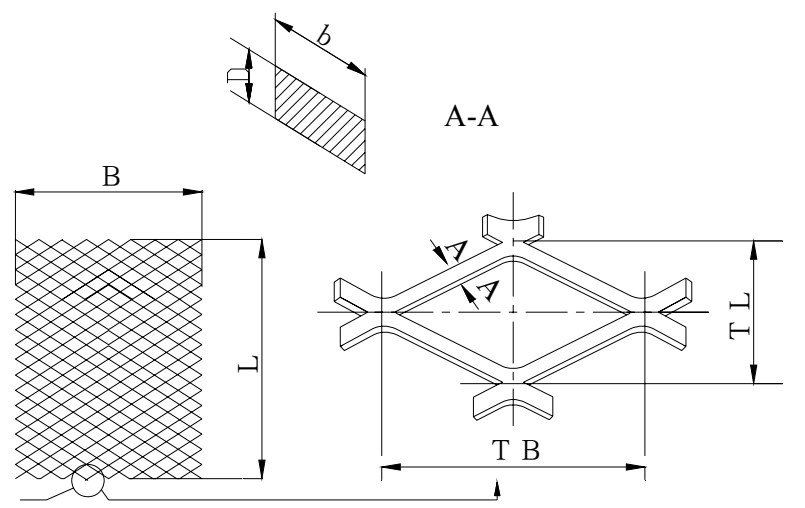

(a)

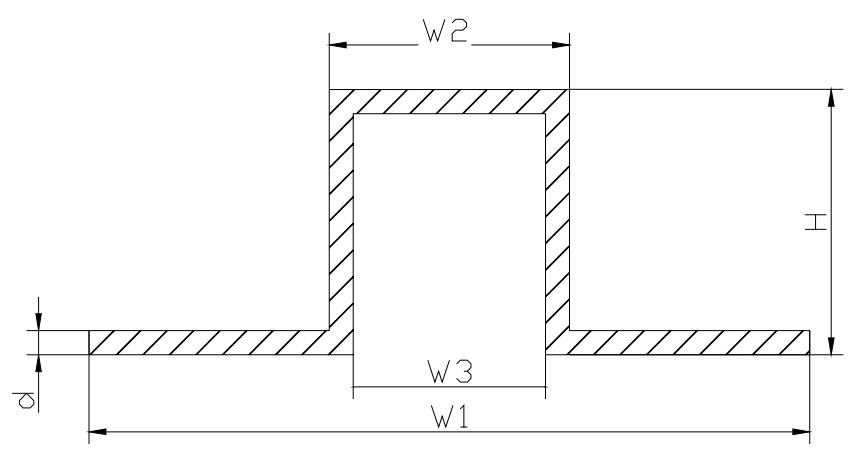

(b) 


\subsubsection{Thermal Performance Evaluation}

\subsubsection{Model Description}

A three-dimension numerical heat transfer model was established based on the structure illustrated in Figure 4; the calculation domain was chosen as a solid with a width of $480 \mathrm{~mm}$, a length of $500 \mathrm{~mm}$ and the height from the EPS to the rooftop. The following assumption was made to simplify the solution process: the solid and liquid involved have constant physical properties. Afterwards, a 3-dimensional steady energy equation was established as [7]:

$$
\rho C_{\mathrm{p}} \frac{\partial T}{\partial t}+\nabla \cdot(-k \nabla T)=0
$$

The finite element method was used to solve this equation. Figure 6 shows the boundaries and heat fluxes acting on the solid model.

Figure 6. Boundary conditions of the solid model.

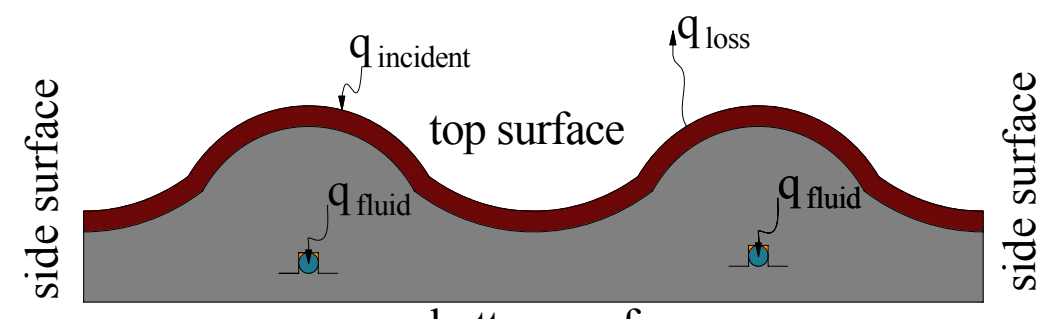

bottom surface

The boundary conditions were set according to the solar roof construction. For the side surfaces, front (back) surface and the bottom surface, because the heat transfer there is quite weak, the adiabatic boundary condition was used:

$$
-k \nabla T=0
$$

The top surface is the main area where the heat transfer happens. Solar heat gains and panel heat loss both occur. The equation representing this energy transfer is given as:

$$
-k_{t} \nabla T_{t}=I+h_{a}\left(T_{t}-T_{a}\right)
$$

where $T_{t}$ and $T_{a}$ represent the temperatures of tile surface and ambient temperature; $h_{a}$ is the heat transfer coefficient between tile surface and the ambient; $I$ is the solar insolation. The equation used for the interfacial heat transfer between the working fluid and surrounding solid is:

$$
-k \nabla T=h_{f}\left(T-T_{f}\right)
$$

where $T$ and $T_{f}$ are the temperature of the surrounding solid and main fluid temperature, $h_{f}$ is the heat transfer coefficient between the main fluid and the surrounding solid.

Further equations to calculate the convective coefficients are as follows [31]:

$$
\begin{aligned}
& h_{f}=0.023 \operatorname{Re}^{0.8} \operatorname{Pr}^{0.4} \\
& h_{\mathrm{a}}=h_{c}+h_{r}
\end{aligned}
$$


where $h_{c}$ and $h_{r}$ means the convection heat loss coefficient and the radiation heat loss coefficient, respectively. The convective heat transfer coefficient from the top surface to the ambient, $h_{c}$, is also known as the wind coefficient and the radiation heat transfer coefficient from the concrete collector surface to the sky, $h_{r}$, was described by Watmuff et al. [32,33]:

$$
h_{c}=2.8+3.0 v
$$

where $v$ means the wind velocity.

$$
h_{r}=\frac{\sigma\left(T_{s k y}^{2}+T_{t}^{2}\right)\left(T_{s k y}+T_{t}\right)}{\frac{1}{\varepsilon_{s k y}}+\frac{1}{\varepsilon_{t}}-1}
$$

where $\sigma$ means the Boltzmann constant; $T_{s k y}$ and $T_{t}$ mean the sky temperature and tile surface temperature; $\varepsilon_{s k y}$ and $\varepsilon_{t}$ means emittance of the sky and the roof tile [34]:

$$
\varepsilon_{s k y}=0.006 T_{d p}+0.74
$$

Where $T_{d p}$ means the ambient dew point temperature:

$$
T_{s k y}=\varepsilon_{s k y}^{1 / 4} \cdot T_{\mathrm{a}}
$$

\subsubsection{Simulation Results and Analysis}

The ceramic tile has an absorbtivity of 0.85 , and the same emissivity. The climate conditions used were determined in accord with the typical day data from Tianjin. Constant inputs are equal to the daily average values and the solar irradiation and ambient temperature are $400 \mathrm{~W} / \mathrm{m}^{2}$ and $0{ }^{\circ} \mathrm{C}$, respectively. The wind speed and dew point are $2.1 \mathrm{~m} / \mathrm{s}$ and $-5.8^{\circ} \mathrm{C}$, respectively. $\varepsilon_{s k y}$ and $T_{s k y}$ were calculated by Equations (9) and (10), Respectively. Figure 7 gives the mesh generated during simulation and the related results, respectively. Figure 7a shows that the mesh is not evenly generated because the size of different component relies on different magnitudes, and in order to save calculation time while maintaining the accuracy, local uneven meshes are needed. Figures $7 \mathrm{~b}$ and $7 \mathrm{c}$ gives the temperature and heat flux distributions among the simulation domain. The temperature difference between the tile surface and the fluid in the tube was no more than $11{ }^{\circ} \mathrm{C}$, and the heat flux was relative evenly distributed, with an average heat flux of $350 \mathrm{~W} / \mathrm{m}^{2}$ based the top surface of the roofintegrated collector. The overall area of the roof-integrated collector is about $260 \mathrm{~m}^{2}$, the total heat flow is about $91 \mathrm{~kW}$ under the simulation conditions, much higher than the building heat load calculated previously by eQUEST. Therefore, it is feasible to apply such a roof integrated solar collector as a heat source for the heat pump. 
Figure 7. The simulation mesh and results. (a) Mesh; (b) Temperature; (c) Heat flux.

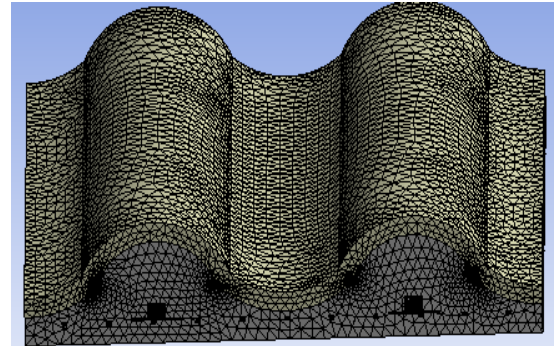

(a)

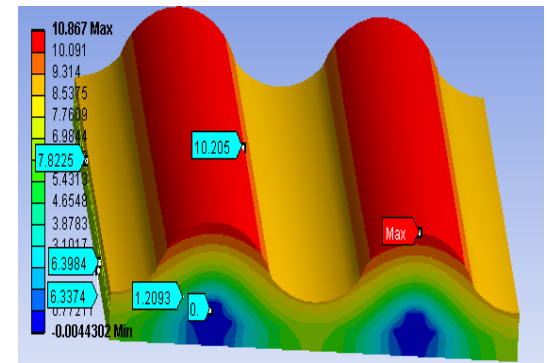

(b)

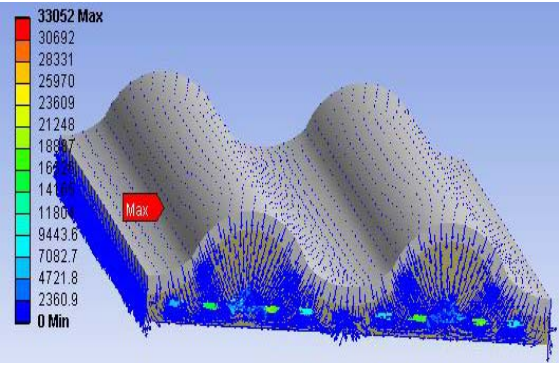

(c)

\subsection{The Coupled Heat Pump}

The system used four scroll compressors with single-phase induction motors, whose displacement at $50 \mathrm{~Hz}$ is $33.2 \mathrm{~m}^{3} / \mathrm{h}$, with a rated power of $8820 \mathrm{~W}$. Figure 8 shows a picture of the actual system. The system also has the function of cooling the building in summer. A thermostatic expansion valve was used for the system, which maintains constant superheat at the inlet of the compressor by regulating the mass flow rate of the refrigerant with the help of a feeler bulb. The temperatures were measured with $0.1{ }^{\circ} \mathrm{C}$ precision by thermal resistor sensors at various locations in the system and the building. The power consumption of the system was also measured by a Wattmeter. The heat pump was set on the first floor to ensure system stability and less noise. Table 2 gives the technical specifications of the major equipment.

Figure 8. The picture of the real system.

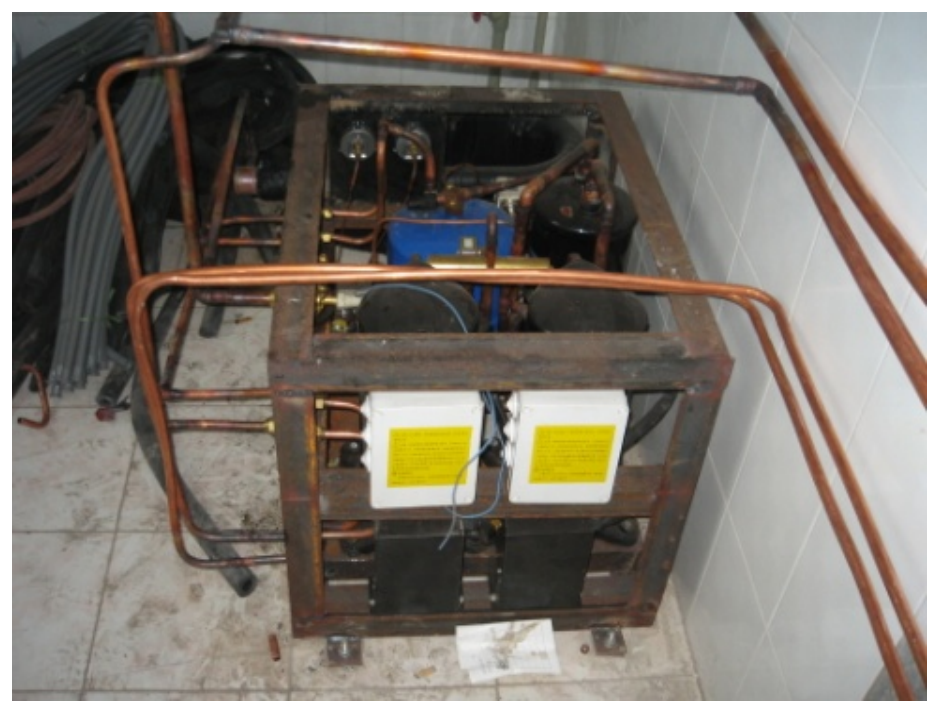

Table 2. Technical specifications of the major equipment.

\begin{tabular}{ccc}
\hline Name & Amount & Technical Parameter \\
\hline Scroll Compressor & 4 & rated cooling capacity of $8.8 \mathrm{~kW}$ \\
Expansion Valve & 2 & rated cooling capacity of $19.1 \mathrm{~kW}$ \\
Condenser & 1 & heat interchanging area of $6 \mathrm{~m}^{2}$ \\
Evaporator & 1 & heat interchanging area of $5 \mathrm{~m}^{2}$ \\
Pump & 2 & pumping head of $25 \mathrm{~m}$, flow discharge of $6 \mathrm{~m}^{3} / \mathrm{h}$ \\
\hline
\end{tabular}




\subsection{The Radiant Floor Heating System}

Figure 9 shows the schematic structure of the demonstrated radiant floor heating system. Different from the conventional type, the tube buried underneath is galvanized steel tube, not PE. The tube has an inner diameter of $20 \mathrm{~mm}$ and the tube thickness is $2.75 \mathrm{~mm}$; the space between two tubes is $400 \mathrm{~mm}$; the depth of buried pipe is $40 \mathrm{~mm}$ from tube center to the floor tile top surface. Moreover, the floor construction is much simpler than the conventional one, since no additional layers or thickness are added, compared to the conventional floor construction.

\section{Real-Detected Performance of the Solar-Assisted Heat Pump}

The real performance of the demonstrated solar-assisted HP system was tested from January 1 to January 8 in 2009. Figure 10 shows the room temperature and for comparison, the outside air temperature. Both curves in the Figure 9 have fluctuations, the reason for this is that large south-facing windows brought in a lot solar heat during the daytime. Meanwhile, the room temperature averaged at $18.9^{\circ} \mathrm{C}$, which meets the design standard in Tianjin city.

Figure 9. Schematic of the radiant floor.

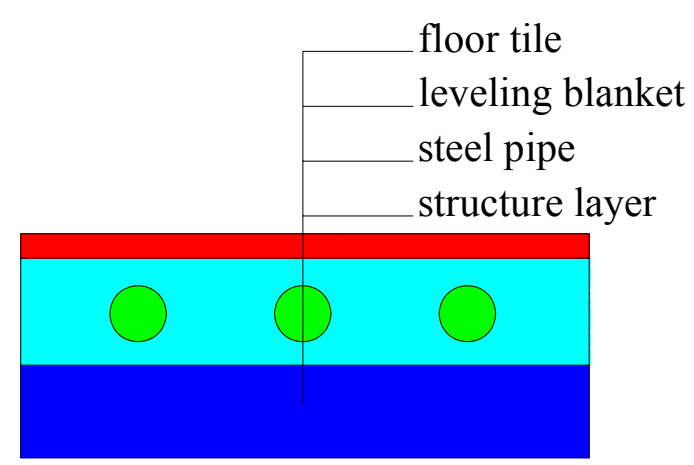

Figure 10. Room temperature and environment temperature during test.

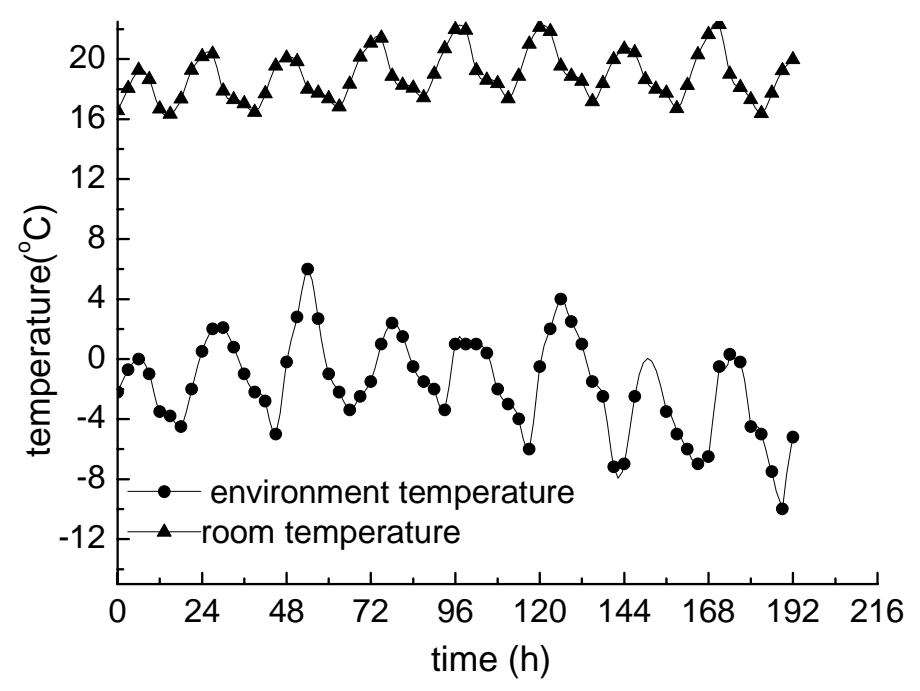


The heat supply and the electric power consumption of the system in the 8 days are shown in Figure 11a.

Figure 11. Energy and performance analysis results of the system. (a) Thermal and electrical energy; (b) COP.

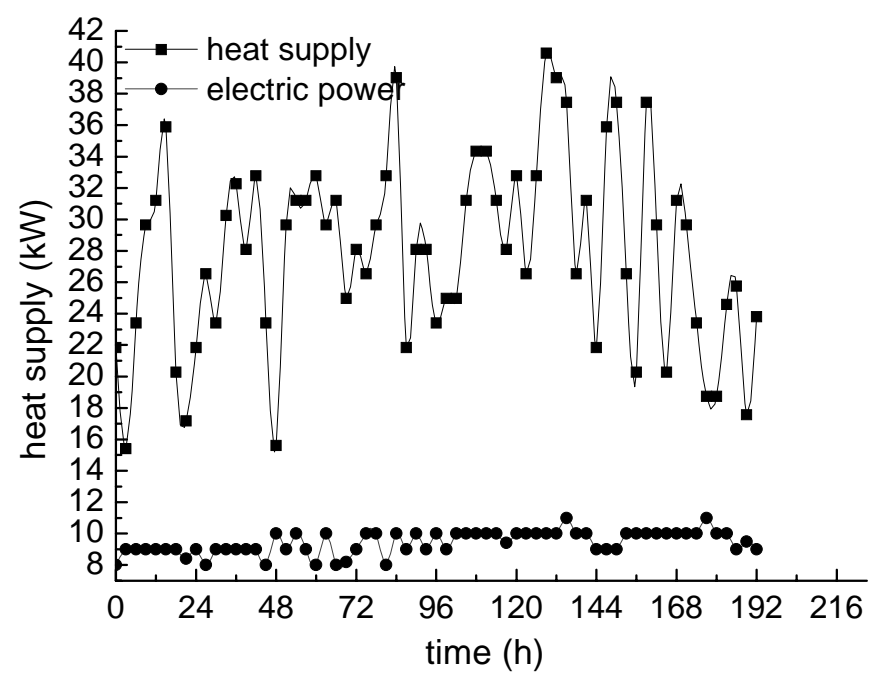

(a)

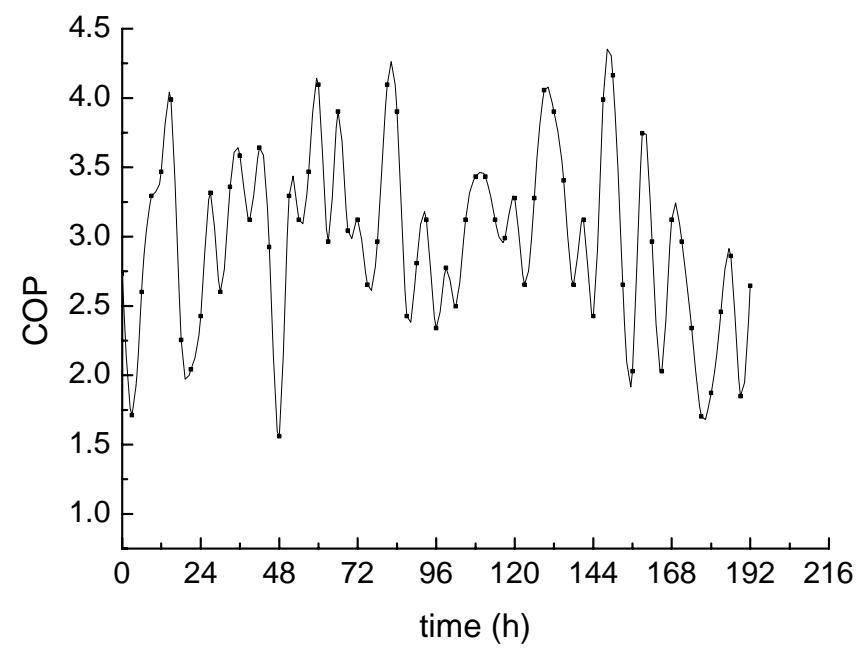

(b)

The electricity usage is always less than $10 \mathrm{~kW}$, which is a small value for a villa of $820 \mathrm{~m}^{2}$. Figure $11 \mathrm{~b}$ gives the calculated COP values for the demonstrated system using the thermal energy supplied and the electricity consumed during the test period. It can be seen that the COP of the heat pump fluctuates depending on the environmental conditions during the test period in winter; the average COP is 2.97 , and the maximum value reaches 4.16 , a relatively high value for winter weather.

\section{Conclusions}

In the present study, a SAHP system which consists of a refrigerant filled collector, a scroll compressor and a radiant floor heating unit with a legend roof integrated solar collector was designed and demonstrated. The legend roof integrated collector can provide finished surfaces, weatherproofing, 
insulation and energy collection. During the winter of 2009, a series of experimental studies were carried out on the SAHP system. Experimental results show that the system can provide a comfortable living space in winter, with an average COP of 2.97 and a maximum COP of 4.16. The multifunctional SAHP system can guarantee long-term operation under different weather conditions and relatively low running costs during wintertime, but its advantages need to be further proven by more experimental and theoretical studies in the future.

\section{References}

1. Zhai, X.Q.; Wang. R.Z. Experiences on solar heating and cooling in China. Renew. Sustain. Energy Rev. 2008, 12, 1110-1128.

2. Hartkopf, V.; Loftness, S.; Duckworth, S.; Lee, P.; Drake, J.; Rainer, G. The Intelligent Workplace Retrofit Initiative: DOE Building Studies; The U.S. Department of Energy: Washington, DC, USA, 1994.

3. Bopshetty, S.V.; Nayak, J.K.; Sukhatme, S.P. Performance analysis of a solar concrete collector. Energy Convers. Manag. 1992, 33, 1007-1016.

4. Chaurasia, P.B.L. Solar water heaters based on concrete collectors. Energy 2000, 25, 703-716.

5. Bilgen, E.; Richard, M.A. Horizontal concrete slabs as passive solar collectors. Sol. Energy 2002, 72, 405-413.

6. Medved, S.; Arkar, C.; Cerne, B. A large-panel unglazed roof-integrated liquid solar collectorEnergy and economic evaluation. Sol. Energy 2003, 75, 455-467.

7. Abbott, A.B. Analysis of Thermal Energy Collection from Precast Concrete Roof Assemblies. Master's Thesis, Virginia Polytechnic Institute and State University, Blacksburg, VA, USA, 2004.

8. Kara, O.; Ulgen, K.; Hepbasli, A. Exergetic assessment of direct-expansion solar-assisted heat pump systems Review and modeling. Renew. Sustain. Energy Rev. 2008, 12, 1383-1401.

9. MacArthur, J.W.; Palm, W.J.; Lessmann, R.C. Performance analysis and cost optimization of a solar-assisted heat pump system. Sol. Energy 1978, 21, 1-9.

10. Freeman, T.L.; Mitchell, J.W.; Audit, T.E. Performance of combined solar-heat pump systems. Sol. Energy 1979, 22, 125-135.

11. Pedersen, P.V. System design optimization for large building integrated solar heating systems for domestic hot water. Sol. Energy 1993, 50, 267-273.

12. Kaygsuz, K.; Ayhan, T. Exergy analysis of solar-assisted heat-pump systems for domestic heating. Energy Int. J. 1993, 18, 1077-1085.

13. Smith, R.R.; Hwang, C.C.; Dougall, R.S. Modeling of a solar-assisted dessicant air conditioner for residential building. Energy Int. J. 1994, 19, 679-691.

14. Abou-Ziyan, H.Z.; Ahmed, M.F.; Metwally, M.N.; EI-Hameed, A. Solar-assisted R22 and R134a heat pump systems for low-temperature applications. Appl. Therm. Eng. 1997, 17, 455-469.

15. Badescu, V. Model for a solar-assisted climatization system. Energy Int. J. 1998, 23, 753-766.

16. Torres, R.; Picon, N.M.; de Cervantes, G.J. Exergy analysis and optimization of a solar-assisted heat pump. Energy Int. J. 1998, 23, 337-344.

17. Huang, H.; Xinshi, G.; Yuehong, S. Theoretical thermal performance analysis of two solar-assisted heat-pump systems. Int. J. Energy Res. 1999, 23, 1-6. 
18. Ito, S.; Miura, N.; Wang, K. Performance of a heat pump using direct expansion solar collectors. Sol. Energy 1999, 65, 189-196.

19. Esen, M. Thermal performance of a solar-aided latent heat store used for space heating by heat pump. Sol. Energy 2000, 69, 15-25.

20. Badescu, V. Model of a solar-assisted heat pump system for space heating integrating a thermal energy storage unit. Energy Build. 2002, 34, 715-726.

21. Badescu, V. Model of a space heating system integrating a heat pump, photothermal collectors and solar cells. Renew. Energy 2002, 27, 489-505.

22. Badescu, V. First and second law analysis of a solar assisted heat pump based heating system. Energy Convers. Manag. 2002, 43, 2539-2552.

23. Lu, A.; Charters, W.W.S.; Chaichana, C. Solar heat pump systems for domestic hot water. Sol. Energy 2002, 73, 169-175.

24. Badescu, V. Model of a thermal energy storage device integrated into a solar assisted heat pump system for space heating. Energy Convers. Manag. 2003, 44, 1589-1604.

25. Hawlader, M.N.A.; Chou, S.K.; Jahangeer, K.A.; Rahman, S.M.A.; Eugene, L.K.W. Solar assisted heat-pump dryer and water heater. Appl. Energy 2003, 74, 185-193.

26. Sattari, S.; Farhanieh, B. A parametric study on radiant floor heating system performance. Renew. Energy 2006, 31, 1617-1626.

27. Cho, S.H.; Zaheer-uddin, M. An experimental study of multiple parameter switching control for radiant floor heating systems. Energy 1999, 24, 433-444.

28. China Meteorological Bureau; Climate Information Center; Climate Data Office; Tsinghua University; Department of Building Science and Technology. China Standard Weather Data for Analyzing Building Thermal Conditions; China Building Industry Publishing House: Beijing, China, 2005, in Chinese.

29. James, J. eQUEST Introductory Tutorial; Hirsch \& Associates: Anaheim, CA, USA, 2004; pp. 3-4.

30. Medrano, M.; Brouwer, J.; McDonell, V.; Mauzey, J.; Samuelsen, S. Integration of distributed generation systems into generic types of commercial buildings in California. Energy Build. 2008, 40, 537-548.

31. Bejan, A.; Kraus, A.D. Heat Transfer Handbook; John Wiley \& Sons, Inc.: Hoboken, NJ, USA, 2002; pp. 829-831.

32. Duffie, J.A.; Beckman, W.A. Solar Engineering of Thermal Processes; John Wiley and Sons, Inc.: Hoboken, NJ, USA, 1991; pp. 164-165.

33. Duffie, J.A.; Beckman, W.A. Solar Engineering of Thermal Processes: John Wiley and Sons, Inc.: Hoboken, NJ, USA, 1991; pp. 148-149.

34. Clark, E.; Berdahl, P. Radiative Cooling: Resource and Applications; Proceedings of the Passive-Cooling Workshop: Amherst, MA, USA, 1980; pp. 177-212.

(C) 2011 by the authors; licensee MDPI, Basel, Switzerland. This article is an open access article distributed under the terms and conditions of the Creative Commons Attribution license (http://creativecommons.org/licenses/by/3.0/). 